\title{
Reform on the Developing Mode of Pre-service English Teachers in Comprehensive University
}

\author{
Rui HUANG, Zhi-Jiang ZHANG*, Yi-Chun CHEN, Ping WU \\ School of Foreign Languages, Jimei University, Xiamen, China \\ No.185 Yinjiang Rd, Jimei District, Xiamen, Fujian, China 361021 \\ huangrui5678@163.com
}

Keywords: Reform, Pre-service English teacher, Comprehensive University.

\begin{abstract}
Under the "new normal" situation, China is walking into the world at a fast speed and demanding many qualified talents who master English, which make English education become more important than ever before. Pre-service English teacher education plays a decisive role in improving the quality of English education. However, the pre-service English teachers trained by normal colleges and universities cannot meet the demand of the rapidly develop society. After introducing some approbatory modes of pre-service English teacher education at home and abroad, based on the essential qualities of a qualified English teacher and the interview records from six pre-service teachers, the paper analyses the shortcomings of the recent developing mode of pre-service English teachers in comprehensive university in terms of enrollment, curriculum and students' management. To improve the quality of pre-service English education, the paper also put forward some corresponding suggestions, including setting strict admission rules and flexible exiting systems, diversifying curriculum and teaching practice, strengthening the contacts between university and elementary and secondary schools. All these suggestions are helpful to reform the development mode of pre-service English teachers and promote national English education.
\end{abstract}

\section{Introduction}

At present, while normal colleges and universities domestic are reforming their developing modes of pre-service English teachers to meet the new requirements of social development, many comprehensive universities fall behind during reform. These colleges have continued to use the traditional developing mode that fails to develop qualified and social needed English teachers. To seek a new developing mode of pre-service English teachers, many educators and managements in normal colleges and foreign language colleges in comprehensive universities have been coming up with a lot of ideas and opinions. Most of their essays discuss problems about developing mode from the perspective of educator. In fact, to carry out a thorough analysis of current developing mode in comprehensive university, we should also focus on student teachers. The paper interviews six students majoring in normal English in Jimei University and tries to discuss the shortcomings of the developing mode of pre-service English teachers in the comprehensive university. Besides, in the perspective of normal English student, the paper provides some suggestions for the problems, to optimizing current developing mode, and improving the quality of pre-service English teachers' education.

\section{Literature Review}

By reading related books and searching on the Internet for detail information of development modes of pre-service teachers at home and abroad, this paper summarizes two typical developing modes of preservice teachers respectively in America and England; then presents two well-known theories of developing mode of pre-service English teachers in China, including "English + Education" interdisciplinary mode of training talent, and " $1+2+X$ " mode of training pre-service expert teachers. 


\section{Developing Modes of Pre-service Teachers Abroad}

From 1980s, America universities start to research and practice a new five-year integrated model of teacher education. The integrated model means that under a common goal, Curry School of Education and School of Arts and Sciences work together to training pre-service teachers.

High school students enter the School of Arts and Sciences in the University of Virginia by taking the entrance examination, and all students must participate in educational probation in the first year; then students who are interested in teaching submit applications to have educational courses (applicants should have excellent academic record); finally qualified students join the five-year project in Curry School of Education in the University of Virginia in the third year. Graduates must not only finish all the courses arranged by Curry School of Education and the School of Arts and Sciences, but also pass all relative examinations to gain teacher certifications. Graduates will be awarded bachelor's degree, Master of Education Degree and Teacher Certification after meet all the requirements above. ${ }^{[1]}$

Besides the integrated curriculum, the university pays attention to teacher educational courses and emphasizes the integration of theoretical course and practical course. There are different kinds of teaching practice for five years, such as visiting classes, one-on-one teaching instruction, subject teaching practice and full-time internship. During teaching practice, each student has two tutors: one is from the School of Arts and Science, the other from Curry School of Education. The model attaches importance to the cooperation between the School of Arts and Science and Curry School of Education, as well as the relationship of the university and primary and secondary schools.

The partnership mode of initial teacher training in England refers to building a close partnership between universities and primary and secondary schools, to take the advantages of both for training outstanding teachers. The university shoulders the responsibility to impart theoretical knowledge, improve the students' quality and develop pre-service teachers' reflective ability, while the primary and secondary schools play an important role in instructing teaching skills and offering practical opportunities. A formal agreement and some regular meetings are stipulated to strengthen their partnership and improve the quality of cooperation. Pre-service teacher education in England stresses on "school experience" and demands that for four-year bachelor's degree in education, practice course should at least account for 32 weeks; and 24 weeks for two- or three-year bachelor's degree in education ${ }^{[2]}$. In addition to duration of practice, the Ministry of Education makes a series of rules for the whole practice process. Each student has three instructors: an instructor who comes from college education directs theories analysis and experience promotion; a profession instructor in school takes charge of organization; and the practice instructor offer teaching instruction.

\section{Developing Modes of Pre-service English Teachers in China}

\section{TRAINING “ENGLISH +EDUCATION” INTERDISCIPLINARY TALENTS}

Some domestic universities of foreign language start to train inter-disciplinary talents under the framework of English education in 1980s. Training "English + Education" inter-disciplinary talents are one of their experiments. Per-service English teacher education is featured by double-major, which determine that its curriculum based on English and education. Li Hui ${ }^{[3]}$ believes that the integration of English and education must be the core of Per-service English teacher education.

Firstly, aim to training globalization, high-level, integrated and practical talents; secondly, innovate the training scheme to connect pre-service and on-service; thirdly, develop module courses and distinctive courses to achieve the fusion of English and education; fourthly, strengthen the cooperation between university and primary and secondary schools, all kinds of foreign language training institutions in order to solve some problems existing in teaching practice.

\section{“ $1+2+X ”$ MODE OF TRAINING PRE-SERVICE EXPERT TEACHERS}

The " $1+2+X$ " mode of training pre-service expert teachers, refers to the mode which sees teachers' career development as its guideline and production of expert teachers as its aim and where the teachers are educated in a broad scope for one year, instructed to build a solid foundation for two years and receive selective training for $\mathrm{X}$ years. Directed against the disadvantages of undergraduate developing 
mode of training pre-service English teachers, Xu Hong ${ }^{[4]}$ put forward the " $1+2+1$ " mode of training pre-service expert teachers in the view of teacher's professional development in 2015 . The mode focus on educational courses, common courses and subject courses in curriculum, while in teaching management, dedicated unit in university organize a broad scope education in the first year, the corresponding college instructs to build a solid foundation in the second and third year. In addition, students' practical abilities training runs through four academic years, and in the fourth year, more attention is paid to training students' teaching skills by the College of Teacher Education.

\section{The Character of Qualified English Teachers}

According to the document of United Nations Educational Scientific and Cultural Organization, the quality of English education is affected by five elements and their relationship can be summarized in one formula: the Quality of English $=\{$ Student $(1$ point $)+$ Teaching Material $(2$ points $)+$ Educational Environment (4 points) + Teaching Method (3 points) $\} *$ the Quality of Teacher" (qtd. in Quan 76). From the formula, we can easily see the significance of the quality of English teacher. The paper summarizes three characters of a qualified English teacher, they are as following:

\section{Professional Ethics and Professional Perception}

The ideological foundation of English teachers is composed of professional ethics and professional perception, and the combination of them plays adjusting and controlling role in developing qualified English teachers.

An English teacher, in the first place, is a teacher. In China, teachers' professional ethics include patriotism and law-abiding, dedication and devotion, love and concern students, impart knowledge and educate people, and be a model for others. Due to the specificity of English language teaching, English teachers should also be qualified for global vision and international teaching philosophy.

Professional perception of English teachers refers to a psychological activity process of observation, judgment and evaluation of English teacher, which includes three parts: social knowledge and social skills, subject knowledge and professional needs, and comprehensive abilities of teachers.

\section{Knowledge Structure of English Teachers}

Apart from professional ethics and professional perception, the key character for English teachers is possessing specialized knowledge, which is also the core requirement of English teachers. There are three knowledge that a qualified teacher needs, ${ }^{[5]}$ they are general education knowledge, content knowledge and pedagogical content knowledge. General education knowledge, including educational principles, adolescent development knowledge, and cognition and learning knowledge, is the basic knowledge that each qualified teacher must have. Content knowledge of English means that English teachers should not only have outstanding performance in listening, speaking, reading and writing, but also master linguistic knowledge of listening, speaking, reading and writing, because English is a subject and a teaching tool at the same time. Pedagogical content knowledge of English is the most remarkable professional feature for English teacher. Chinese English teachers with pedagogical content knowledge of English know how to create learning opportunities to develop students' language aptitude, when to guide students to training language abilities, and what is the most suitable way to help students' language learning.

\section{Teaching Skills and Research Competence}

Teaching skills define what teachers should be able to do: presenting material, giving clear instructions, correcting errors in various ways, and managing interaction and discipline in classroom, and so on. With teaching skills, English teachers can design teaching steps according to the needs, help students to master English language and develop correct thinking habits, inspire in students an enthusiasm on English learning, as well as exploit students' language potential to reach the teaching goals. In short, teaching skills are the most important criterion for measuring teachers' teaching ability.

Besides English teachers should own research competence means English teachers are good at discovering problems, analyzing problems and coming up with the solutions. With the development of 
research competence and reflection abilities, novice English teachers can grow up to be expert teachers. Therefore, English teachers' educational research competence and reflection abilities have become criteria to judging whether the teacher is professional or not.

\section{Research Design}

This part explains the design of the research including its questions, subjects and instruments and draws on data collected by interview to analyze the present situation of the developing mode of preservice English teachers in the comprehensive university.

\section{Research Questions}

This research tends to find out the present situation of the developing mode of pre-service English teachers in comprehensive university. Below are questions this paper tries to solve:

(1) How do the pre-service English teachers like the current enrollment system? And can it recruit qualified students?

(2) What are the pre-service English teachers' views of curriculum for normal English major in the comprehensive university?

(3) What are the advantages and disadvantages of student management system for normal English major in the comprehensive university?

\section{Research Subjects and Instruments}

The subjects of this research come from six senior students majoring in normal English in the School of Foreign Languages of Jimei University. Two of them have clear and firm faith to working as English teachers, and another two students are unwilling to be English teachers, while the last two students are still hesitating.

This research mainly uses interview to do the investigation. Each interview last for about half an hour, and all of the interview content is preserved by record, then transformed into words. Based on the interview content, this paper analyses the problems existing in the current developing mode of preservice English teachers in the comprehensive university.

\section{Data Analysis and Discussion}

From the investigation results of six pre-service English teachers, this paper analyses the problems existing in the current developing mode of pre-service English teachers in the comprehensive university. To explain the problems clearly, this paper analyses and discusses from three inspects enrollment system, curriculum and student management.

\section{Enrollment System}

The quality of pre-service teachers largely depends on the quality of normal student enrollment. In other words, if normal English major can recruit high quality students, it is more likely to training qualified English teachers. According to Zou Weicheng ${ }^{[6]}$, the relationships of the quality of student enrollment, the quality of future English teacher and English academic achievement of student of future English teacher are as follows:

The quality of student enrollment $\rightarrow$ The quality of future English teacher $\rightarrow$ English academic achievement of student of future English teacher (the arrow means promotion)

As for the quality of pre-service English teacher not only the academic achievement, but also the personality and the willingness for being a teacher should be valued. That is, the enrollment system should make sure that each enrolled student has a good command of English language, as well as the willingness for being a teacher.

However, in the interviews, five of the six pre-service English teachers hold the view that the current enrollment system for normal English major in comprehensive university is not appropriate enough. 
Student A says: "Normal English major requires lower scores when it recruits students early, which does not guarantee the quality of normal students." Student B says that "Some students are transferred to normal English because they failed to be matriculated by the specialties they declared". Student C wonders "Why normal English major just focus on the total score of the college entrance examination and raise no additional requirement for English score?" Student D takes herself as an example "I just want to enter this university, and never mind about the major. In fact, I never thought to be a teacher." Student E says, "Many students, including me, know little about normal English major before choosing it, and we regard early recruitment as another chance to choose university."

From the words of these normal students we can see that the enrollment system for normal English major in the comprehensive university cannot recruit qualified and satisfactory normal students, for it neither guarantee students' willingness for being English teachers, nor make sure each student has a good command of English.

When we mention the willingness for being an English teacher, we must consider students' understanding of normal English major and English teacher. High school students choose their universities and majors according to their scores in college entrance examination. Before the examination, high school students are forced to bury themselves in books, and have no time to consider their colleges, majors and future jobs, however, they have only one month to consider all these important problems after examination. From student B and student E, we can find that some normal English students lack of amply understanding of normal English major and English teacher. Student E also adds: "When I read the college guide book, I was confused and have no idea about the colleges and majors. Finally, I choose English according to my parents' 'wish"'. This is a common phenomenon in China. What's worse, some students do not have any willingness to be English teachers, we can easily find it from student D. The enrollment system of normal English major, inevitably, has enrolled many students who lack of amply understanding of normal English major and have no willingness of being teachers. That brings a lot of teaching problems and management problems during four college years.

Considering normal students' willingness for being English teachers and their mastery of English language, the paper believes the current enrollment system can not recruit qualified students. In general, there are some defects in the enrollment system current developing mode of pre-service English teachers in the comprehensive university.

\section{Curriculum}

The curriculum should be set to meet the need of society and based on the training objectives for students. The curriculum of normal English major is the core of developing mode of pre-service English teachers, which has direct influence on the quality of future English teachers. However, the interviews discover some problems in the curriculum setting. Curriculum arrangement is unreasonable in terms of time. Student C complains that "We wasted a lot of time in the second year because there are few courses arranged, while in the fourth year, we have not enough time and energy to take consideration to TEM8, courses, teaching practice, Test for Teacher Recruitment and looking for jobs at the same time." Most normal colleges and universities set basic disciplinary courses in the first two years and start educational and pedagogical courses in the third year. This kind of curriculum setting has been existed for a long time, and as time goes on, its problems exposed gradually. Considering the specific activities of normal English major, all interviewed students think "it is necessary to adjust the curriculum setting appropriately".

Another problem existing in curriculum of normal English major is lacking pertinence. Student D says: "I don't think I am a normal student, because most of our courses are similar to that of business English." Comparing the curriculum of normal English with the curriculum of business English, the paper finds that apart from thirty same courses, including basic disciplinary courses and specialized courses, business English major only has another four different elective courses, and normal English major has another seven different required courses and three different elective courses. From the statistic, Student D's opinion is reasonable, and it can be concluded that the pertinence of normal English major is not amply. The statistic also shows that the courses of teachers' professional skills are 
far from enough. Deducting the theoretical courses (Pedagogy and Developmental and Pedagogical Psychology), there are only four required courses of professional skills left. As we all know, equipping pre-service English teachers with English teaching skills is a critical objective for normal English education. Finally, about eight-week teaching practice cannot meet the requirement for those students who want to be teachers. Student A who has firm willingness for being an English teacher complains that "Eight-week teaching practice is far from enough". Student B says, "When I was practicing in primary school, I spent most of time in helping the English teacher to check students' homework. Since each student only has two English classes, we have very limited time to teaching English in classroom by ourselves." Student C claims that "Some teachers in primary or secondary schools pay little attention to pre-service teachers, and just let them drift." Another three interviewees think "It is unnecessary for university to force every student to join the teaching practice, because those who are uninterested in teaching can find other jobs during these eight weeks." But in fact, these three students explain that they refuse required teaching practice because they have no willingness for being teachers. That is not the fault of teaching practice, but the mistake of choosing major.

From the interviews, it can be concluded that the curriculum for normal English major fails to meet the requirement of our society and the teaching objectives for normal education, because of its unreasonable arrangement, lack of pertinence and insufficient practical courses.

\section{Student Management}

Currently many universities adopt a "consistent" student management method, that is, normal students from entrance to graduation are always normal students. When asked the advantages of the current student management system, six normal students have similar views. Student A says: "To some extent, this kind of student management meets the social demand of normal talents." Indeed, in the past several decades, our country has confronted with a big problem - the shortage of normal talents, so early enrollment and the "consistent" student management both are effective solutions. Student D adds that "If students can change their major discretionarily, student management will become a great problem. So it is reasonable to a certain extent." From the interviews, we can find there are two advantages of the current student management system: to guarantee the talent supply for teacher staff and to simplify management work.

However, the current "consistent" student management system also brings many problems. Student A says "Students who have no right to drop out from the normal system even if they are unwilling to be teachers after a period of time for English learning. That must be one important reason for low efficiency in class, rejecting teacher and playing hooky." These negative phenomena reduce the efficiency of personnel training of normal university and quality of English normal education. In addition, Student F says that "Doing a job which is irrelevant to normal or teaching after attending all the normal classes for four years, normal students have to spend a lot of time in learning other workrelated knowledge." In some sense, that wastes not only students' valuable time but also the limited education resource. On the other hand, some non-normal students who have enthusiasm on teaching and determined to devote themselves to education have no opportunities to achieve their goals in life. For the normal system, it is a great loss.

In general, the current student management system lacks flexibility. Even if it has advantages, such as making sure the talent supply and providing convenience to managers, it binds the development of students' future careers, which at the same time has negative impacts on the quality of normal education.

\section{Suggestions to reform the Developing Mode of Pre-service English Teachers}

In order to solve the problems in the developing mode of pre-service English teachers, there are three aspects which we should do: to set serious admission rules and flexible exiting systems, to diversify curriculum and teaching practice, and to strengthen the university-schools cooperation.

To Set Admission Rules and Exiting System 
A flexible exiting system is an effective method to optimize the talent structure of normal system. Students without willingness of being teachers are often unsatisfied with the curriculum and treat teaching practice negatively, and even violate the rules and regulations in university. All their negative behaviors become heavy burdens for school managers. There should be liberation for those students to leave normal system, and on the other hand, can alleviate burdens on university. When allowing nonnormal students enter the normal system and normal students drop out from normal system on halfway, normal universities must focus on professional education from the beginning, in order that students have comprehensive understandings about teachers and teaching jobs, as well as develop into qualified pre-service teachers with loyalty.

\section{To Diversify Curriculum and Teaching Practice}

Most current curricula for normal English major combine of English major course with educational course simply, which cannot cultivate qualified English teachers to meet the needs of English teaching in primary and secondary schools. Therefore, it is necessary for pre-service teacher educators to pay more attention to the curriculum. Above everything, courses about English teaching, which highlight the characteristics of normal English major, should be increased, such as skill training for English teachers, English teaching strategies, and teaching design and case study. In addition, integrate English content courses into education courses, to focus on English education and meet the demand of normal English major. Finally, provide more elective courses which are close related to English teaching in primary and secondary schools to diversify the courses.

Considering the current novitiate and teaching practice cannot meet the requirement, maximizing opportunities for teaching practice is the key to improve the situation. There are some suggestions: Firstly, to start the novitiate from the first year. In every term, normal students go to primary and secondary schools to observe English class and acquaint themselves with English teaching. Secondly, to invite experienced English teachers to give lectures, reports and teaching demonstration in university. Thirdly, to host teaching skills contest regularly and encourage students join it. By this way students can improve their teaching skills in contest. Fourthly, to add new practice methods to provide students more practice chances, such as the aid-the-poor practice teaching program and supporting education activity in winter and summer vacation. Finally, to adjust the time for teaching practice. For example, arrange twelve-week rather than eight-week for teaching practice and the teaching practice can be carried twice, once in the third year and again in the fourth year.

\section{To Strengthen the University-schools Cooperation}

Freeman ${ }^{[7]}$ says, "Teacher education will need to organize and support new relationships between new and experienced teacher." That is, the normal universities should pay more attention to the relationship between pre-service teachers and experienced teachers. Therefore, to strengthen the university-schools cooperation is indispensable. By means of inviting experienced English teachers from primary and secondary schools to instruct pre-service English teachers and organizing pre-service English teachers to visit primary and secondary schools, normal university and primary and secondary schools can training qualified English teachers together. In short, the primary and secondary schools shall become another training place and take more responsibility to develop future teachers. On the other side, university teachers should strengthen the communication with the primary and secondary schools' teachers and know more about English teaching in primary and secondary schools, so as to cultivate qualified pre-service English teachers for schools. By this way, we can take the advantages of university and the primary and secondary schools and develop qualified teachers who have professional knowledge and solid teaching skills.

\section{Conclusion}

The investigation on pre-service English teachers' view on developing mode of pre-service English teachers in the comprehensive university is useful to reform the current developing mode and promote the quality of English teacher education and the development of national English education. Through the analysis and discussion of the interview, it can be concluded that currently there exist a series of 
problems in developing mode of pre-service English teachers in the comprehensive university. To solve these problems, the paper comes up with three useful suggestions, which are helpful for educators and managers of normal English major to cultivate more outstanding pre-service English teachers. However, this research is conducted on the limited samples and research methodology, and the interview time is too short to have a specific and comprehensive understanding of the problems, therefore the conclusions may not be comprehensive. So in the future studies, more pre-service English teachers from different grades and different comprehensive universities need be chosen to enlarge the investigation scope. There is still a long way to go to reform the developing mode of pre-service English teachers in comprehensive university.

\section{Acknowledgements}

This work was supported by the funding of Education Committee of Fujian Province and Jimei University, the Number of the project is JAS160272 entitled A Study on the Evaluation Strategy of High School English Teaching from Perspective of the New College Entrance Examine.

\section{References}

[1] Zhang, Xiaoli. 2011. "An Analysis of the Five-year Consistent Teacher Education Model at the University of Virginia in USA", Foreign Education Research, 38(8): 70 -75.

[2] Li, Ping. 2010. "The Enlightenment of British Teacher Education on Teacher Education in Comprehensive Universities in China", Education and Teaching Research, 24(8):1-12.

[3] Li, Hui.2013. International and Foreign Language Teacher Education Reform Path and Innovation Research, Journal of Chinese Education, 45(9):65-68.

[4] Xu Hong.2015. "An Analysis of the "1+2+1" Teacher Education Model in the Context of Teacher Professionalization”, Journal of Jianghan University, 32(2): 118-128.

[5] Freeman, Donald. 1989. "Teacher Training, Development, and Decision Making: A Model of Teaching and Related Strategies for Language Teacher Education". TESOL Quarterly, 23(1): 27-44.

[6] Zou, Weicheng. 2009. Research on Basic English Teacher Education in China, Shanghai: East China Normal University Press.

[7] Freeman, Donald. 2002. "The Hidden Side of the Work: Teacher Knowledge and Learning to Teach". Language Teaching, 35(1): 1-13. 